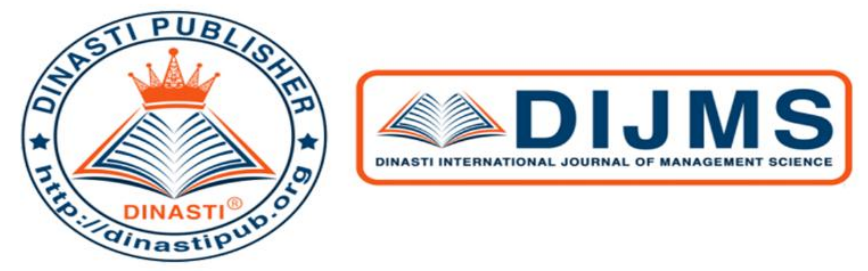

$+6281387654578 ?$

$+6281387654578 @$

https://dinastipub.org/DIJMS (-)

dinasti-info@gmail.com G.

\title{
CANVAS BUSINESS STRATEGY IN THE APPLICATION OF LOCAL CREDITS IN BANK BCA
}

Yohan Tirtayasa

Universitas Mercu Buana, Jakarta, Indonesia

\begin{tabular}{|c|l|}
\hline $\begin{array}{c}\text { ARTICLE INFORMATION } \\
\text { Received: } 17^{\text {th }} \text { May } 2020\end{array}$ & $\begin{array}{l}\text { Abstract: In meeting the needs of additional funds, } \\
\text { BCA has taken into account the needs of customers; } \\
\text { Revised: } 21^{\text {st }} \text { June } 2020 \\
\text { provided in the form of credit facilities. The business } \\
\text { model of this local credit facility has been well } \\
\text { thought out so as to make this facility in demand } \\
\text { among customers. Analysis uses } 9 \text { business model } \\
\text { Corresponding author: } \\
\text { Yohan Tirtayasa } \\
\text { E-mail: }\end{array}$ \\
$\begin{array}{l}\text { segments ranging from determining customer } \\
\text { segments, value propositions, channels, customer } \\
\text { relationships, revenue streams, key resources, key }\end{array}$ \\
activities, key partnerships, and cost structure. These \\
9egments will be interrelated to support BCA as a \\
whole and in line with the vision, mission, values, \\
needs and other activities of BCA.
\end{tabular}

Keywords:. Canvas Business, BCA Bank

DOI:10.31933/DIJMS

\section{INTRODUCTION}

PT. Bank Central Asia (BCA), Tbk is a banking company that has been established since February 21, 1957. BCA is one of the largest private banks in Indonesia, even in the top 10 best banks in Southeast Asia. BCA has always been committed to being the main bank in the community by providing various solutions and banking services to support the economic process of the community. BCA always brings innovations in its banking transactions, such as internet banking facilities, features for withdrawing and depositing money at an ATM machine, to the feature of withdrawing money without a card; making BCA a pioneer in presenting banking innovations in providing facilities to its customers.

As a bank that aspires to become the mainstay of the community, BCA provides a variety of solutions for all segments of the community, both as individual customers and organizational customers, as well as for both consumptive and productive needs. One of the solutions provided by BCA in productive needs is local credit, working capital financing needs for business customers who need additional working capital, both as a company and individually. The development of this solution provides answers to customers who need additional capital to support their business. By providing working capital loans, making BCA capable as a bank that helps in economic development. 
Customers who are targeted in this solution are business customers both from corporate entities (PT, CV, firms, etc.) to individual customers who have a business that has been running for at least 2 years and have working capital needs analyzed by a team of analysts. Bank Central Asia is a bank that is trusted by the public and has customers reaching 14 million customers, committed to carry out its main function as a bank, namely a financial institution that collects funds from the public and channels them in the form of loans (loans) for both consumptive and productive needs. For example, the product we discussed is a loan product for productive needs (working capital). According to their needs, this loan is channeled if the debtor exists or has working capital requirements that can be analyzed through the BCA credit analyst team.

\section{Vision and Mision}

The vision of Bank BCA is to become the bank of choice for the community, which acts as an important pillar of the Indonesian economy. While the mission of Bank BCA is as follows:

1. Building superior institutions in the field of payment settlement and financial solutions for business customers and individuals.

2. Understand the various needs of customers and provide appropriate financial services for achieving optimal customer satisfaction.

3. Increasing the value of francais and the value of BCA stakeholders

\section{LITERATURE REVIEW}

\section{Business strategy}

Business strategies almost always start with what can happen and not start with what happens. The occurrence of new market innovation speeds and changes in consumer patterns requires core competencies. Change needs to look for competencies to find core competencies in the business being carried out. (Umar, 2003). According to David (2011), business strategy is a tool to achieve long-term goals. A company must strive to achieve competitive advantage in a sustainable manner, in the form of (1) continually adapting to change in external trends and internal capacities, capabilities and resources; and (2) effective planning, implementation and evaluation of strategies that play a large role (David, 2011).

\section{Business Model Canvas}

Business Model Canvas is a business model of a logical picture of how an organization creates, delivers and captures value (Osterwalder, 2010). There are 9 basic elements that pay attention to how to think of an organization both profit and non-profit. These elements include Customer Segments, Value Propositions, Channels, Customer Relationships, Revenue Streams, Key Activities, Key Partnerships, Key Resources and Cost Structure (Permana, 2013).

The explanation of the nine boxes according to (Wardhanie, 2017) includes:

a) Customer Segments are people who use the services / products of the organization and those who contribute in providing income for the organization. Customer segmentation can also be sorted based on behavior, age, profession, income and geography.

b) Value Propositions are various kinds of products and services that will create value for certain segment customers. Product quality is a factor to support purchasing 
decisions, Brata (2017). The main reason customers switch one product or service to another is whether they really know which product or service is solving the problem, or meeting primary needs. (Piñeiro, Et Al, 2017) design, product usability.

c) Chanel, an element such as communication, distribution and sales channel that states how the organization communicates with its segment customers and communicates its value proposition.

d) Customer Relationship, fostering relationships with customers, with the aim of getting new customers and retaining old customers.

e) Revenue Streams or inflows of funds that describe how the organization earns cash income from each customer segment. The flow of funds is what makes a company survive.

f) Key Resources describe the most important assets that determine the successful operation of a business model, such as buildings, vehicles, intellectuals and labor.

g) Key Activities are the main activities that support the success of a business model in sending its value proposition to customers.

h) Key Partnership, a business cooperation agreement that is voluntarily initiated between two or more companies to complete a particular project. This collaboration can lead to cost savings, reduce risk and obtain resources that are not owned by the company.

i) Cost Structure describes all costs that arise as a result of operating this business model in order to realize value propositions through appropriate, reliable channel channels, key resources, activities.

\section{RESEARCH METHODOLOGY}

This research uses a qualitative approach with descriptive methods. This means that the data and fact disclosure procedures that researchers use are non-statistical or nonmathematical (Moleong, 2006). Qualitative data are personal documents, field notes, words and actions of respondents and supporting documents. Thus, this research method will reveal the actual state according to the results obtained in the study by measuring based on quality.

\section{Result and Discussion}

In the business canvas analysis, there are nine elements including the following: customer segments, value propositions, channels, customer relationships, revenue streams, key resources, key activities, key partnerships, and cost structure.

\section{Customer Segments}

Customer segments are parties that use products from the company. Customers here are not only customers who bring profits directly, but they can also be customers who are supporting the increase in revenue from the company. So in the company, BCA is committed to carrying out its main function as a bank, a financial institution that collects funds from the public and distributes them in the form of loans (loans) for both consumptive and productive needs. Empathy map analysis is carried out to obtain a picture of how consumers' insights on BCA.

For example, the product we discussed is a loan product for productive needs (working capital). According to their needs, this loan is channeled if the debtor exists or has working capital requirements that can be analyzed through the BCA credit analyst team. Broadly speaking, BCA's local credit segment customers are targeting as shown in Table 1.1 below.

Table 1.1 Customer Segment of BCA 


\begin{tabular}{|c|c|c|c|c|c|}
\hline & $\begin{array}{l}\text { Open } \\
\text { Market }\end{array}$ & $\begin{array}{l}\text { Niche } \\
\text { Market }\end{array}$ & $\begin{array}{l}\text { Segmented } \\
\text { Market }\end{array}$ & $\begin{array}{l}\text { Market } \\
\text { Diversivication }\end{array}$ & Multi Market \\
\hline $\begin{array}{l}\text { For whom } \\
\text { we make } \\
\text { Value } \\
\text { Proposition }\end{array}$ & $X$ & $\mathrm{X}$ & $\begin{array}{l}\text { Yes, working } \\
\text { capital needs to } \\
\text { support a } \\
\text { business that is } \\
\text { practically easy } \\
\text { and safe. }\end{array}$ & $\begin{array}{l}\text { Yes, the need to } \\
\text { meet the } \\
\text { convenience for } \\
\text { productive } \\
\text { transactions. }\end{array}$ & $\begin{array}{l}\text { Yes, the need } \\
\text { for a network of } \\
\text { customers who } \\
\text { save and } \\
\text { customers who } \\
\text { need credit. }\end{array}$ \\
\hline $\begin{array}{l}\text { Who are the } \\
\text { main } \\
\text { customers? }\end{array}$ & $\mathrm{X}$ & $\mathrm{X}$ & Businessman & $\begin{array}{lr}\text { Already a } \\
\text { customer and } \\
\text { potential customer }\end{array}$ & $\begin{array}{l}\text { Customers who } \\
\text { place their funds } \\
\text { in BCA and } \\
\text { customers who } \\
\text { have credit at } \\
\text { BCA }\end{array}$ \\
\hline $\begin{array}{l}\text { Who brings } \\
\text { in revenue? }\end{array}$ & $\mathrm{X}$ & $\mathrm{X}$ & $\begin{array}{l}\text { Business } \\
\text { customers who } \\
\text { use local credit } \\
\text { facilities. }\end{array}$ & $\begin{array}{l}\text { Potential } \\
\text { customers }\end{array}$ & $\begin{array}{l}\text { Business people } \\
\text { who use local } \\
\text { credit facilities. }\end{array}$ \\
\hline $\begin{array}{l}\text { Who is a } \\
\text { Value } \\
\text { Proposition } \\
\text { user? }\end{array}$ & $\mathrm{X}$ & $\mathrm{X}$ & $\begin{array}{l}\text { Business } \\
\text { customers who } \\
\text { need additional } \\
\text { working capital. }\end{array}$ & $\begin{array}{l}\text { Potential } \\
\text { customers }\end{array}$ & $\begin{array}{l}\text { Businessman } \\
\text { who needs local } \\
\text { credit facilities. }\end{array}$ \\
\hline
\end{tabular}

\section{Value Proposition}

Value proposition contains unique / different things and the advantages offered by BCA products. As a bank that aspires to become the mainstay of the community, BCA provides a variety of solutions for all segments of the community, both as individual customers and organizational customers, as well as for both consumptive and productive needs. One solution provided by BCA in productive needs is local credit.

Local credit can meet the needs of working capital financing for business customers (who need additional working capital), both as a company and individually. The development of this solution provides answers to customers who need additional capital to support their business. By providing working capital loans, making BCA capable as a bank that helps in economic development.

\section{Channel}

Channel is the media of a company or organization that functions to communicate with customers / customers. The aim is to deliver value propositions from BCA products. The Following are channels from BCA :

a) Channels used in lending are through branch offices, sub-branch offices, AO / RO visits, and e-form submissions through the BCA website. 
b) $\mathrm{BCA}$ is considered by customers to be quite well-known with banks that are quite strict in their credit requirements and in-depth analysis. BCA tries to change the mindset of the community by providing potential data, which customers are most likely to need it, and assigning an AO / RO team to offer these facilities to their customers.

c) To create an attractive credit program rather than competitors, the company also provides an interest reduction facility for new submissions as well as an interest reduction for the commitment to use certain fixed facilities to retain existing customers.

d) To ensure the customer's accountability in returning the funds, the bank certainly binds the customer with collateral that can be either fixed assets or non-fixed assets by being bound by a credit agreement until a certain period of time based on the agreement of both parties which must be renewed annually.

e) BCA also provides channels: the priority of BCA is the rapid disbursement process with trusted and safe internet banking facilities, so that when customers need funds immediately, BCA can provide and stay transacted only through internet banking, or cash slips (Checks and Bilyet Giro).

\section{Customer Relationship}

Customer relationships are an effort by BCA companies to foster relationships with customers. So that customers who are targeted in this product are customers who have a business, so in conducting customer relationships with organizational customers, BCA approaches the decision makers and / or stakeholders in the company or organization concerned. Whereas for individual customers, BCA takes a direct approach to the customers concerned.

\section{Revenue Streams}

Revenue streams contain plans for income from BCA products. Then the flow of funds received by BCA from customers who buy local credit products are as follows:

a. Transaction Revenue: administration fees and fees charged once a year, if the customer extends the facility.

b. Recurring income: recurring income divided into:

i. Usage fees: interest costs charged to customers in accordance with the use of their credit facilities, subject to $13 \%$ of the loan, debited every 25 th of the month in accordance with the amount and period of use of these funds.

ii. Subscription fees: provision fees and administrative fees charged to customers when customers extend their credit facilities, as well as insurance costs.

\section{Key Resources}

Existing resources will be developed by the company; in accordance with the strategy determined by the company to achieve the vision and mission that have been determined; and the integration of all these resources is called capabilities. The following are the main things that are owned by BCA as its main capabilities: "BCA has a good supply chain based on the trust of all related parties: customers from funding and lending; coupled with the support of technology and Human Resources (HR) who are qualified to manage the available funds. "

The development of existing resources and competencies that are only owned by the company is referred to as Core Competitive. BCA's core competitive is to have a team to conduct a good analysis so as to minimize Non-Performance Loans (NPLs). 


\section{Key Activities}

Key activities are important activities that support the success of BCA companies or organizations to realize the value propositions that we offer. Then the value offered by BCA by becoming a relationship banking for its customers, BCA employees are trained to obey the main values of BCA, namely Customer Focus.

They are expected to be at the forefront in providing the best and perfect service in realizing BCA as a one stop banking solution. So that the key activities of BCA are: key activities in providing banking solutions in realizing one stop banking solutions.

\section{Key Partnership}

In improving the quality, income / income, and relationships of the BCA, the BCA needs partners related to BCA products. So that BCA has the advantage of paying close attention to its partners: funding, lending, and other stakeholder customers as balanced business partners.

BCA as a banking company that is closely related to its customers, BCA makes customers who have 19.5 million accounts that they serve as their main partners. BCA strives to provide the best service to its customers. With the tagline "Always by Your Side" BCA strives to provide banking solutions to its customers. By carrying out the functions of commercial banks regulated by Bank Indonesia as the parent bank in Indonesia, BCA is also overseen by the Financial Services Authority (OJK) in carrying out its daily operations. By collecting funds from the public in the form of savings and deposits, BCA also provides investment products for its customers in the solution to the customers. BCA also provides a flow of funds to other customers in the form of productive loans and consumer loans.

\section{Cost Structure}

The cost structure contains costs that BCA budgeted for making and running BCA products. Then the cost structure for BCA customers by segmenting local credit products is as follows:

a. Cost Driven: Reducing transactions in branches so that the use of operational funds is cheaper. One way is to develop banking transactions via the internet, BCA implements socialization for its customers to use transactions through Klik BCA Bisnis, by queuing at the branch, creating costs for the company through employees and branch office operations. By transferring customers' transactions to internet banking, reducing the amount of costs incurred by BCA.

b. Its characteristics are as follows:

i. Fixed Cost

By reducing the number of customers coming to the branch office, BCA shifted the fixed costs of employee salaries to the operational costs of the branches to the cost of developing their technology, for example the development of a cash withdrawal deposit machine reduced the number of employees / employees serving for the transaction, and through the development of the internet banking is also considered capable of reducing the level of customer arrivals to the BCA branch office.

\section{ii. $\quad$ Variable Cost}

Development costs, in presenting innovation, the company first conducts research before the facility or product is launched to consumers.

iii. Economies of Scale

The company seeks to develop by presenting new branch offices in major cities in Indonesia and expanding branch offices to make it easier to reach customers. 
iv. Economies of Scope

Disbursing credit to the public so that the company reduces the burden of paying interest on existing funding customers. So that the available funds can be channeled and deposit the funds as small as possible (adjusting to the minimum Liability Debt Ratio (LDR) stipulated by Bank Indonesia). 


\section{Business Model Canvas}

\begin{tabular}{|c|c|c|c|c|}
\hline \multirow[t]{2}{*}{$\begin{aligned} & \text { Key Partnerships } \\
& 1 . \text { Customers } \\
& \text { (corporate, } \\
& \text { consumer, } \\
& \text { commercial and } \\
& \text { SME) } \\
& 2 . \text { Shareholders } \\
& 3 . \text { Financial Services } \\
& \text { Authority (OJK) } \\
& 4 . \quad \text { Bank Indonesia } \\
&(\mathrm{BI})\end{aligned}$} & $\begin{array}{l}\text { Key Activities } \\
\text { 1. } \begin{array}{l}\text { CRM by the RO team to carry out } \\
\text { opportunity solutions }\end{array} \\
\begin{array}{cl}\text { 2. } \\
\text { Internet banking for customers' } \\
\text { b. Pusiness activities }\end{array} \\
\text { Personal banker for one stop solution }\end{array}$ & \multirow{2}{*}{$\begin{array}{ll}\text { Value Propositions } \\
\text { 1. } & \text { Fast performance by } \\
\text { AO / RO } \\
\text { 2. } & \begin{array}{l}\text { Customization per } \\
\text { customer }\end{array} \\
\text { requirements } \\
\text { 3. } \quad \begin{array}{l}\text { Getting the job done } \\
\text { provides appropriate } \\
\text { credit }\end{array} \\
\text { 4. } \quad \begin{array}{l}\text { Accessibility for } \\
\text { additional working }\end{array} \\
\text { capital } \\
\text { 5. } \quad \begin{array}{l}\text { Status to get credit } \\
\text { so as not to interfere } \\
\text { cashflow }\end{array} \\
\text { Usability for } \\
\text { expansion funds }\end{array}$} & $\begin{aligned} \text { Customer } & \text { Relationships } \\
1 . & \text { CRM by } \\
& \text { AO/RO } \\
\text { 2. } & \text { And personal } \\
& \text { AO / RO for } \\
& \text { priority } \\
& \text { customers } \\
3 . & \text { ATM machines } \\
4 . & \text { Internet banking } \\
\text { 5. } & \text { Gathering for } \\
& \text { customers }\end{aligned}$ & \multirow[t]{2}{*}{$\begin{array}{cl}\text { Customer Segments } \\
\text { 1. } & \begin{array}{l}\text { Business } \\
\text { customers (small }\end{array} \\
& \text { and medium) } \\
\text { 2. } & \text { Commercial } \\
\text { 3. } & \text { Corporations }\end{array}$} \\
\hline & 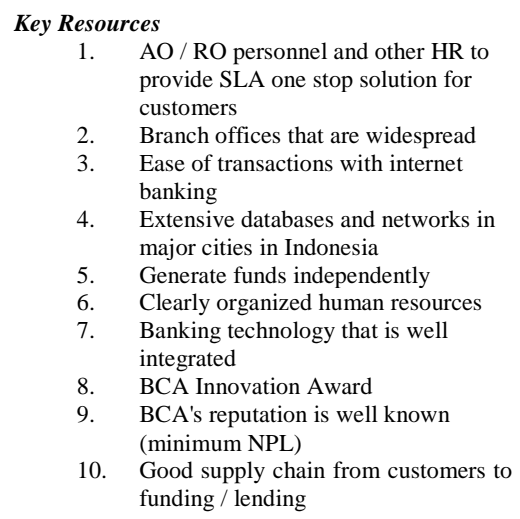 & & $\begin{aligned} & \begin{array}{r}\text { Channels } \\
\text { 1. }\end{array} \text { Internet banking } \\
& \text { 2. } \text { Branch office } \\
& \text { 3. } \begin{array}{l}\text { Referral of } \\
\text { existing }\end{array} \\
& \begin{array}{l}\text { customers } \\
\text { 4. }\end{array} \\
& \text { Website } \\
& \text { 5. } \text { www.bca.co.id } \\
& \begin{array}{l}\text { Provision, } \\
\text { interest and }\end{array} \\
& \text { administration } \\
& \text { details } \\
& \text { 7. } \text { Credit binding } \\
& \text { 8. } \text { Feedback SLA } \\
& \text { Ceiling } \\
& \text { monitoring by }\end{aligned}$ & \\
\hline \multicolumn{2}{|c|}{$\begin{array}{cl}\text { Cost Structure } \\
\text { 1. } \\
\text { 2. } & \text { Operational funds (employee salaries, technology development } \\
\text { 3. } & \text { Presenting new branch offices in major cities in Indonesia } \\
\text { 4. } & \text { Flowing funds in accordance with the LDR set by BI }\end{array}$} & $\begin{aligned} \text { Revenue } & \text { Streams } \\
\text { 1. } & \text { Administration and } \mathrm{p} \\
\text { 2. } & \text { cost for using credit } \mathrm{f} \\
\text { 3. } & \text { Subscription costs } \\
\text { 4. } & \text { Insurance costs }\end{aligned}$ & $\begin{array}{l}\text { sion cost } \\
\text { ities }\end{array}$ & \\
\hline
\end{tabular}

Business Model Canvas (BMC) which can be compiled from the discussion above can be seen in the following table. 


\section{CONCLUSIONS AND SUGGESTION CONCLUSIONS}

At the local credit facility, the target customers are customers (business and corporate) who need additional funds to smooth the cash flow of their business. The value proposition to be conveyed is quick performance by $\mathrm{AO} / \mathrm{RO}$, Customization per customer needs, Getting the job done providing appropriate credit, Accessibility for additional working capital, Status to get credit so as not to disrupt cash flow, and Usability for expansion funds.

Channels are well chosen and developed by: having a branch office; also the internet banking website as a means of delivering product values to customers and building good relationships (customer relationships). To make things easier, there are details of costs to be incurred, credit agreements that are monitored well by AO and customers have the right to make feedback back to employees. The program is also tailored to the specific needs of customers.

\section{SUGGESTION}

The assessment must also be harmonized with the Key Performance Indicator (KPI) established by the BCA Bank. The analysis is conducted in two directions: what should be done and activities that are actually assessed by the BCA Bank. This is needed to see if there is still a gap between the actual and ideal BCA bank employees working in the local credit division, to meet all business segments properly so as to advance BCA as a whole.

\section{REFERENCES}

Ali, Hapzi. (2020). Module 9 BC, Canvas Business Models, Diversification and Balance. Jakarta: Mercu Buana University

Bank Central Asia (BCA). (n.d.). VISION AND MISSION BCA. from BCA: https://www.bca.co.id/id/About-BCA/Corporates/Find- Know- About-BCA/Visionand-Mission (quoted May 17, 2020)

Brata, BH., Husani, S., Ali, H. (2017). The Influence of Quality Products, Price, Promotion, and Location to Product Purchase Decision on Nitchi At PT. Jaya Swarasa Agung in Central Jakarta. Saudi Journal of Business and Management Studies. Vol-2, Iss-4B (Apr, 2017):433-445 433-445

David, Fred R, (2011). Strategic Strategic Management Concepts, 12th Edition, Salemba Empat, Jakarta.

Moleong, Lexy J. (2006). Qualitative Research Methodology, Bandung, Rosda Karya Youth; Revised Edition.

Osterwalder, A and Pigneur, Y. (2010). Business model generation: a handbook for visionaries, game changers, and challengers. New Jersey: John Wiley \& Sons, Inc.

Permana, D. J. (2013). Analysis of print media business opportunities through the canvas model business approach to determine new business strategies. ISSN exacta factor: 1979-276X, 6 (4), 309-319.

Piñeiro, F.Et Al (2017). Business Models On Startups : A Multicase Study. Vol 10(5), pp792807 